\title{
INCREASED POLLINATOR ACTIVITY IN URBAN GARDENS WITH MORE NATIVE FLORA
}

\author{
FUKASE, J. $^{1}-$ SIMONS, A.M. ${ }^{2 *}$ \\ ${ }^{1}$ Institute of Environmental Science, Carleton University, Ottawa, ON, KIS 5B6, Canada \\ ${ }^{2}$ Department of Biology, Carleton University, Ottawa, ON, K1S 5B6, Canada \\ (phone: +1-613-859-1135; fax: +1-613-520-3539) \\ *Corresponding author \\ e-mail: andrew_simons@carleton.ca \\ (Received $7^{\text {th }}$ Jun 2015; accepted $19^{\text {th }}$ Dec 2015)
}

\begin{abstract}
Declining pollinator abundance has become a major global environmental concern. Almost $90 \%$ of flowering plants rely on animal pollinators for reproduction, and negative effects of pollinator declines on crop production have been shown. Urbanization is at least partially responsible for pollinator declines, and public programs have been developed to encourage pollinator-friendly gardens. Here, in an observational study, we investigate the relationship between pollinator activity and the proportion of native species in unmanipulated private gardens in an urban area. Pollinator activity in each of ten gardens was recorded at nine times throughout the growing season. Pollinator frequency differed among gardens, and visitation was positively associated with percent area planted with native species, after correcting for effects of time of year, plant density and total garden area. The effect of proportion native plant area on pollinator activity differed among pollinator guilds, and was particularly strong for bumble bees and large bees. The observation of heightened pollinator activity with increasing native area in this correlational study suggests that cultivating native plant species should be encouraged in urban gardens. We discuss that, although such observational studies have the advantage of realism, they cannot determine underlying causal factors driving the observed correlation.
\end{abstract}

Keywords: exotic plant species; native flora; pollinator decline; urbanization

\section{Introduction}

The decline of domesticated and wild insect pollinators has become a global environmental concern (Potts et al., 2010; Stokstad, 2006; Thomann et al., 2013), and a high priority in conservation efforts (Gallai et al., 2009; Withgott, 1999). For example, several Bombus species are in serious decline across North America (Cameron et al., 2011; Colla et al., 2012), Ireland (Fitzpatrick et al., 2007), and declines are occurring in parallel in Britain and the Netherlands (Biesmeijer et al., 2006). Habitat lost to human activity including urbanization is considered to be a major cause of pollinator decline (Connor et al., 2002; Matteson and Langellotto, 2011; Vanbergen et al., 2013), prompting a movement for pollinator friendly gardens, often encouraging the cultivation of native flowering plant species. However, the effectiveness of the relative "nativeness" of gardens in promoting pollinator activity is still unresolved. Here, in an observational study, we investigate whether the proportion of native plants in urban gardens affects pollinator activity, and thus whether the inclusion of native flora should be considered in the development of programs to promote pollinator conservation.

Both managed and wild insect pollinators, such as honey bees (Apis sp.) and bumblebees (Bombus sp.), play ecologically and economically crucial roles in both natural and human-altered environments (Ashman et al., 2004; Gallai et al., 2009; Klein et al., 2007; Potts et al., 2010). Close to $90 \%$ of all flowering plants are pollinated by 
animals (Ollerton et al., 2011), and 35\% of global food production depends, at least in part, on animal pollinators (Klein et al., 2007). The demand for agricultural products requiring animal pollinators has increased with population increases in recent decades (Aizen and Harder, 2009; Calderone, 2012), and the estimated annual value of pollination services provided by insect pollinators in the United States reached $\$ 15.1$ billion in 2009 (Calderone, 2012). Negative effects of pollinator decline on global crop production and reproduction of wild flowers has been documented (Aizen and Feinsinger, 1994; Biesmeijer et al., 2006; Gallai et al., 2009).

Much research aims to investigate and explain the causes of pollinator decline. There are several possible causes, and there is growing consensus that declines are multifactorial (Bryden et al., 2013; Vanbergen et al., 2013) and include habitat loss and fragmentation through intensification of land use (Aizen and Feinsinger, 1994; Connor et al., 2002); competition with invasive pollinator species (Thomson, 2004); diseases such as Varroa destructor mite infection (Finley et al., 1996) and the Israeli acute paralysis virus (Cox-Foster et al., 2007); exposure to pesticides (Brittain et al., 2010), and reduced floral diversity as a result of invasive plant species (Dietzsch et al., 2011; Koutika et al., 2011; Simons, 2003).

Potential pollinator habitat is limited by available green space in urban areas. However, the use of private gardens is increasingly being recognized for its potential contribution to pollinator conservation through the provision of habitat with a high diversity of flowering plants (Comba et al., 1999; Goddard et al., 2010; Matteson and Langellotto, 2011). The effectiveness of urban gardens in pollinator conservation is expected to depend on the composition of the garden (McFrederick and LeBuhn, 2006). Specifically, the selection of particular plant species can account for much of the activity of insect pollinators such as bumblebees (Goulson et al., 2008; Thomson, 2004). Conservation programs provide information on how to create a "pollinator friendly" garden, often encouraging the cultivation of native plant species rather than non-native ornamentals and invasive species (Mysliwy, 2014). However, knowledge of the effectiveness of planting native species in attracting diverse and abundant insect pollinators is still needed. Existing studies (Corbet et al., 2001; Frankie et al., 2005; Tuell et al., 2008) were designed specifically to examine pollinator attraction using prescribed flower choices, and no study to date examines pollinator attraction and degree of garden nativeness in unmanipulated gardens.

In this study we ask whether the degree of nativeness influences pollinator attraction in intact gardens by monitoring pollinator foraging activity in ten urban gardens with different compositions of flowerbed area, plant density and the proportion of area planted with native flora. We address several questions; two basic to pollination, and two more focused on effects of nativeness: 1) whether pollinator abundance changes through the growing season and/or in response to ambient temperature; 2) whether the effect of time of year on pollinator activity differs among pollinator type or "guild"; 3) whether the proportion of garden area planted with native species (as well as plant density and total garden area) affects pollinator activity; 4) because pollinators may differ in their degree of host range specialization, whether the effect of nativeness on visitation frequency differs among pollinator guilds. 


\section{Material and methods}

\section{Measures of garden variables}

The ten gardens for the study were selected with the assistance of the Backyard Habitat Program established by the Canadian Wildlife Federation. The gardens were located in two main municipal districts separated by a distance of $12 \mathrm{~km}$ within the greater Ottawa, ON region: three in Centretown and seven in Lincoln Fields. Gardens within each area were selected on the basis of the feasibility of sampling every area within a two-day window for dates throughout the season. Two properties had distinct back and front gardens, and these were considered separate based on differences in floral composition. In each garden, floral area, plant density, and the area planted with native species were measured in mid-May (Table 1). Floral area was measured as the total area of flowerbeds. Some gardens had two to several flowerbeds, whereas a few had a single large flowerbed. Plant were identified to species, and density was estimated as the count of individual stems divided by the flowerbed area. In gardens that were large and densely planted, a randomized $1 \mathrm{~m}^{2}$-quadrat sampling technique was applied. A "proportion native area" value was calculated for each garden as the proportion of total flowerbed area sown with native species. These proportions (p) were transformed as arcsine $\left(\mathrm{p}^{\wedge} 0.5\right)$ to improve normality. To reduce sampling error in estimates of pollinator activity in large gardens, two plots were established for the six gardens > $50 \mathrm{~m}^{2}$, and means of measurement values across plots were used in analyses. To avoid random selection of anomalous plot areas, plot location was selected subjectively, based on representative flora and density of flowering plants.

Table 1. Characteristics of the ten selected study gardens in Ottawa, ON. Total area represents the cultivated area within the garden.

\begin{tabular}{llllll}
\hline Garden & Location & $\begin{array}{l}\text { Total area } \\
\left(\mathrm{m}^{2}\right)\end{array}$ & $\begin{array}{l}\text { Plant } \\
\text { density } \\
\left(\mathrm{stems} / \mathrm{m}^{2}\right)\end{array}$ & $\begin{array}{l}\text { Native } \\
\text { flower area } \\
\left(\mathrm{m}^{2}\right)\end{array}$ & $\begin{array}{l}\text { Proportion } \\
\text { native area }\end{array}$ \\
\hline 1 & LF & 145.81 & 47 & 45.97 & 0.315 \\
2 & LF & 144.74 & 106 & 27.30 & 0.189 \\
3 & LF & 32.50 & 21 & 6.52 & 0.201 \\
4 & LF & 70.86 & 57 & 17.02 & 0.240 \\
5 & LF & 29.93 & 71 & 3.73 & 0.125 \\
6 & LF & 53.39 & 229 & 2.81 & 0.526 \\
7 & LF & 25.85 & 10 & 0.08 & 0.030 \\
8 & CT & 68.07 & 17 & 1.17 & 0.172 \\
9 & CT & 39.15 & 30 & 0.46 & 0.118 \\
10 & CT & 52.27 & 20 & 1.36 & 0.260 \\
\hline
\end{tabular}

$\mathrm{LF}=$ Lincoln Fields, $\mathrm{CT}=$ Centretown

\section{Measures of pollinator frequency}

Pollinator activity was observed in each garden plot on nine dates spanning July $3^{\text {rd }}$ to September $13^{\text {th }}$. Because pollinator activity is influenced by temperature, observations were conducted only if the temperature was between $15^{\circ} \mathrm{C}$ and $30^{\circ} \mathrm{C}$, and were postponed in cases of severe rainfall. Observations of gardens in Lincoln Fields and Centretown were conducted on consecutive days due to time constraints. 
Observations were made between 8:30 and 17:30, and the order in which gardens were visited within each area was randomized for each day. Summary weather conditions (temperature and sun index) were recorded for each observation. At each plot, two 10minute observations were conducted, and the mean value of the two observations was used to calculate pollinator frequency (pollinators per minute).

All flower visitors initially present and all new visitors observed foraging within the plot were monitored, although not all flower-visiting insects are effective pollinators (Schemske et al., 1978). Potential pollinators were photographed rather than collected for identification during observation, and were categorized into nine guilds: bumblebee (Bombus sp.), honey bee (Apis sp.), small bee (halictid and colletid bees), large bee (megachilid, and andrenid bees), small fly (syrphid flies), large fly (calliphorid and bombyliid flies), wasp (vespids), butterfly (lepidopterans), and other invertebrates (e.g. coleopterans), and counted. Events were scored as pollinator activity only if physical contact was made with the flower; those pollinators merely traversing the plot were ignored. This sampling method may overestimate true pollinator activity, but it does not lead to bias across plots because all observations were made by a single researcher (Hennig and Ghazoul, 2012).

\section{Statistical analyses}

Second-degree polynomial (quadratic) regression was first performed to assess seasonal change in frequency of overall pollinator visitation. The residuals from this quadratic fit were then used to ask whether there is also an effect of temperature on pollinator activity independent of time of year. To account for overall changes in pollinator activity through the season, "residual pollinator activity" from this quadratic fit was used as the response variable in analyses as noted below. To ask whether the change in pollinator activity through the season differs among pollinator guilds, we used a mixed-model ANOVA where pollinator guild is a fixed effect, and day and the interaction are random effects.

A preliminary one-way ANOVA was conducted to test for variation in the frequency of total pollinator visitation among gardens (where the response variable is residual pollinator activity, above), followed by a post-hoc Tukey test. To address the main question of the effect of native plants on pollinator activity, multiple regression was used to simultaneously examine the effect of proportion native, plant density and flower area on residual pollinator activity to account for possible covariation among predictor variables. Finally, ANCOVA was used to ask whether the effect of proportion native flora differs among pollinator guilds, where proportion native, plant density, total area are continuous, and pollinator guild is categorical. All analyses were performed using SPSS 18.0 or JMP 10.0 .

\section{Results}

A total of 1699 pollinators were recorded over the observation period. Although it explains less than $10 \%$ of the variance, quadratic regression shows a highly significant change in pollinator abundance through time $\left(\mathrm{R}^{2}=0.087, \mathrm{~F}_{141}=6.70, \mathrm{P}=0.002\right)$. Therefore, to correct for the effect of time of year, these residuals were used as pollinator frequency values in the following analyses. (Linear regression would not be an appropriate analysis of pollinator abundance $v s$. time of year, because pollinator abundance is lowest at both ends of the season.) Using the residuals from this quadratic 
fit in a linear regression (there is no apparent nonlinear effect of temperature) shows no independent effect of temperature on pollinator activity after correcting for time of year $\left(\mathrm{R}^{2}=0.015, \mathrm{~F}_{142}=2.21, \mathrm{P}=0.14\right)$.

Much variation was observed among pollinator guilds in average frequencies of visitation (Figure 1), with small bees showing highest frequencies, followed by bumblebees, with lowest frequencies observed for butterflies. Furthermore, the relative abundance of pollinator guilds differed across dates (Figure 2): bumblebee and honeybee abundance increased mid to late season while small bees were common in early summer and persisted throughout the summer. Large bees and dipteran pollinators appeared early in the observation period although their frequencies were generally lower than that of bumblebees, honeybees and small bees. This pattern is confirmed by the significant interaction between pollinator guild and time of year (Table 2).

Table 2. Mixed-effects ANOVA results for effect of pollinator guild and time of year on total pollinator frequency. Guild is a fixed, whereas Day and the interaction terms are random effects. Because different pollinator guilds may appear at different times during the season, Day was treated as a categorical effect.

\begin{tabular}{lclll}
\hline Effects & df & Mean square & F & P \\
\hline Pollinator guild & 8 & 267.23 & 14.47 & $<0.001$ \\
Day & 8 & 46.07 & 2.50 & 0.020 \\
Pollinator guild*Day & 64 & 18.46 & 1.93 & $<0.001$ \\
\hline
\end{tabular}

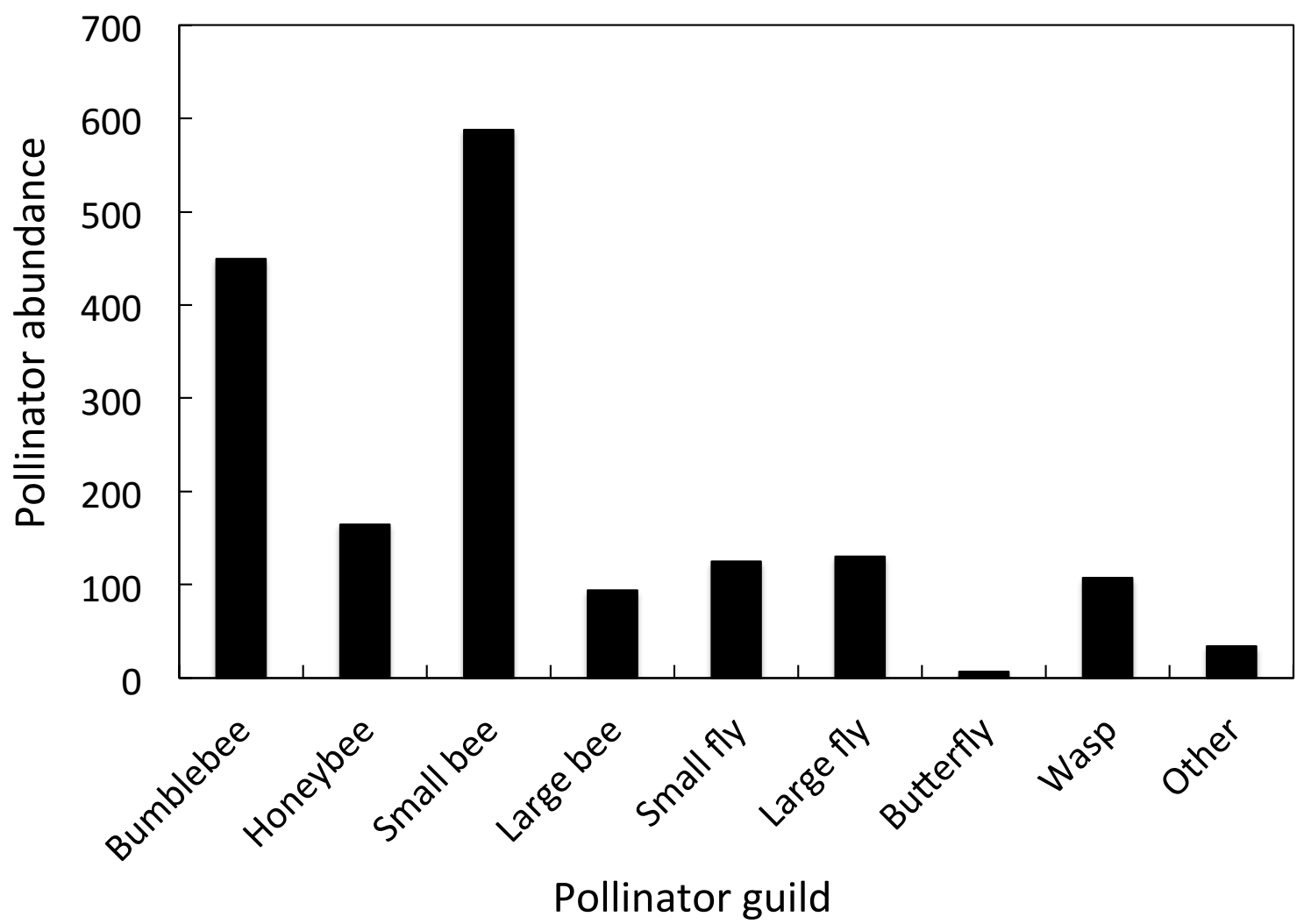

Figure 1. The total abundance of each of the nine pollinator guilds observed in urban garden plots in Ottawa, ON. Values are from counts conducted for two, ten-minute periods for each plot on nine occasions from the beginning of July through mid September. 


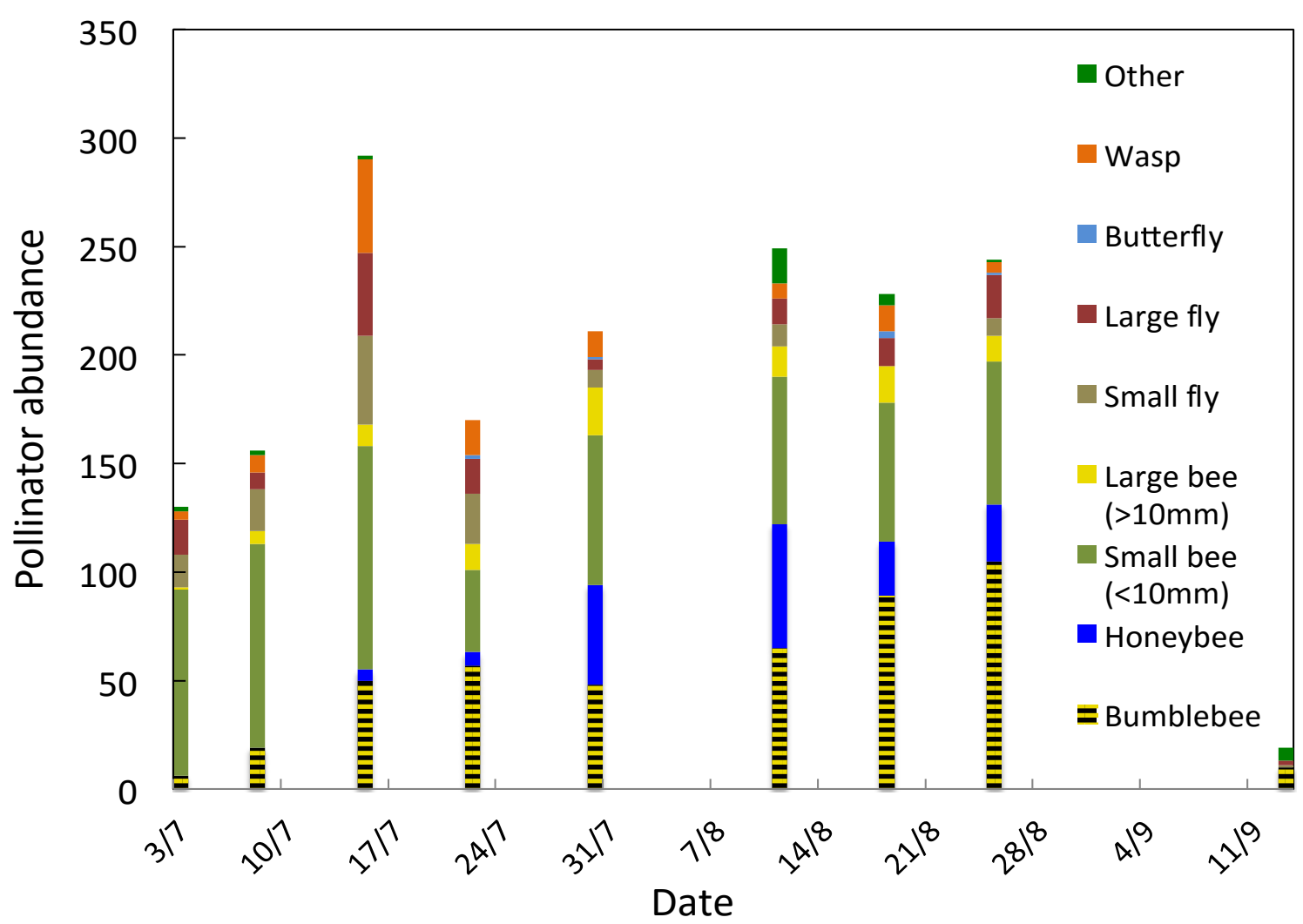

Figure 2. The abundance of each of the nine defined pollinator guilds across the nine observation dates. Values represent total counts conducted for two, ten-minute periods for each plot from the beginning of July through mid September.

A one-way ANOVA shows that there was a highly significant difference in the frequency of (residual) pollinator visitation among gardens $\left(\mathrm{F}_{9,134} ; \mathrm{P}<0.001\right)$. A post-hoc Tukey test further reveals that differences in the average frequency of pollinator visitation was largely attributable to differences between two subsets; a group of four $(6,7,8,9)$ and two $(3 \& 4)$ gardens (Table 3$)$.

Table 3. Post-Hoc Tukey HSD test from one-way ANOVA for differences among gardens in pollinator activity. For the Tukey HSD column, values not sharing a letter are significantly different.

\begin{tabular}{|c|c|c|c|}
\hline $\begin{array}{l}\text { Pollinator activity } \\
\text { (frequency) }\end{array}$ & Garden \# & $\begin{array}{c}\text { Transformed } \\
\text { proportion native area }\end{array}$ & Tukey HSD \\
\hline 1.375 & 4 & 12.04 & $\mathrm{a}$ \\
\hline 1.544 & 3 & 10.05 & $a b$ \\
\hline 0.928 & 1 & 15.83 & $a b c$ \\
\hline 0.909 & 2 & 9.45 & $a b c d$ \\
\hline 0.769 & 10 & 1.30 & $a b c d$ \\
\hline 0.400 & 5 & 6.24 & $b c d$ \\
\hline 0.313 & 9 & 0.59 & $c d$ \\
\hline 0.209 & 6 & 2.63 & $\mathrm{~d}$ \\
\hline 0.144 & 7 & 0.15 & d \\
\hline 0.297 & 8 & 0.86 & $\mathrm{~d}$ \\
\hline
\end{tabular}


Multiple regression (Table 4) including proportion native area, plant density and total area $\left(\mathrm{R}^{2}=0.251\right)$ confirmed a highly significant independent effect of proportion native plant area on residual pollinator activity. The independent effect of plant density was also significant, with no evidence for an effect of total area. There are no qualitative differences in results if pollination activity is used as the response variable instead of the residuals from the quadratic regression of pollinator activity on time of year.

Table 4. Multiple regression of proportion native area, plant density, and total planted area on pollinator activity. Proportion native area was arcsine-squareroot transformed, and pollinator activity was corrected for time of year (see text).

\begin{tabular}{lllcc}
\hline Effects & Estimate & SE Estimate & T-ratio & $\mathrm{P}$ \\
\hline Intercept & -6.924 & 2.12 & -3.27 & 0.001 \\
Proportion native area & 38.21 & 6.61 & 5.78 & $<0.001$ \\
Plant density & -0.033 & 0.01 & -2.51 & 0.013 \\
Total area & -0.042 & 0.03 & -1.48 & 0.141 \\
\hline
\end{tabular}

Although the slopes of the relationships between activity and proportion native area have positive values for all pollinator guilds (Figure 3), analysis of covariance (ANCOVA) shows that the effect of proportion native area on activity differs among pollinator guilds (Table 5): a significant interaction between pollinator guild and the degree of garden nativeness exists (Table 6).

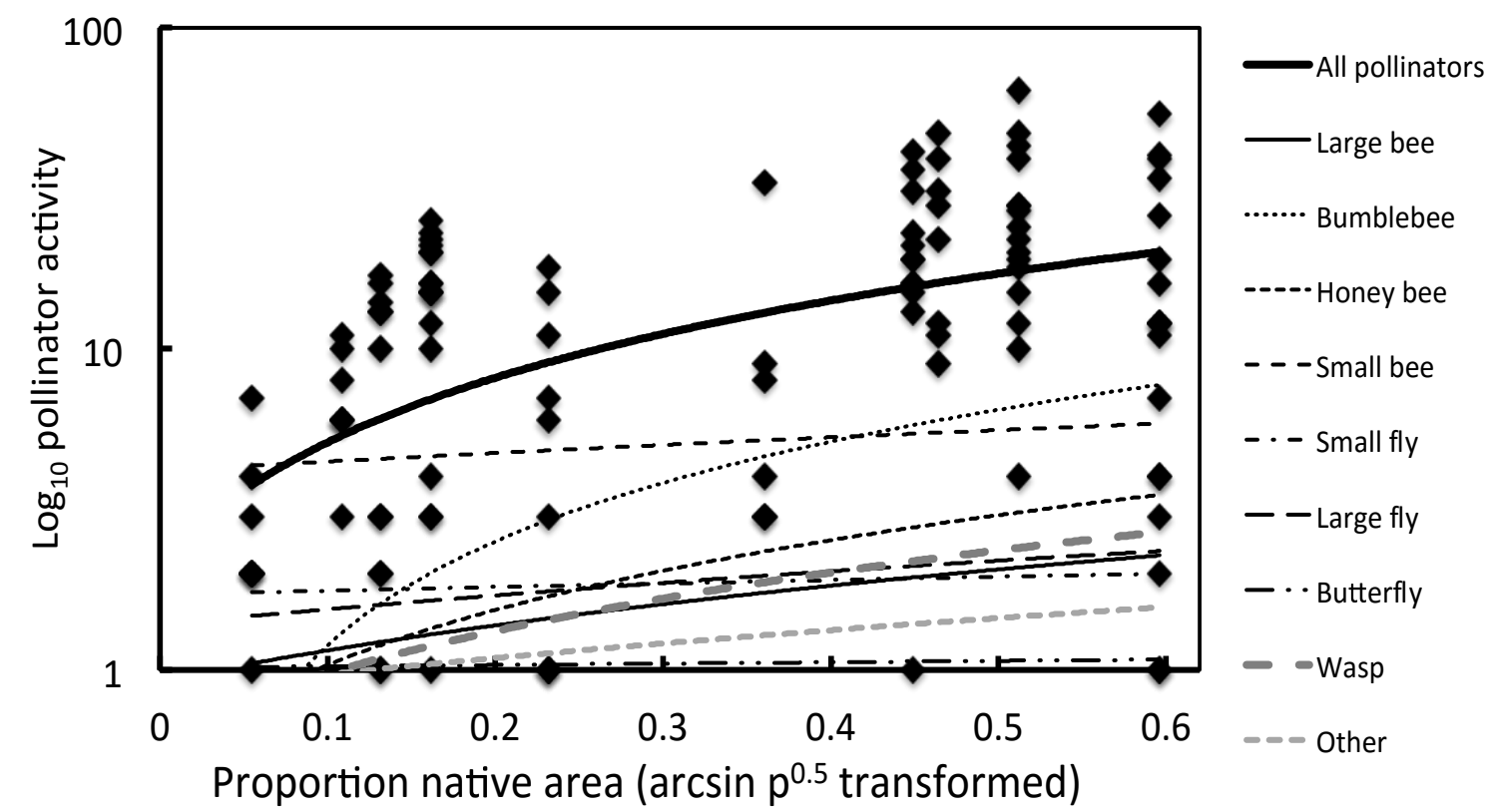

Figure 3. Relationship between observed activity for each of the pollinator guilds and the proportion of urban garden area planted with native plants. The category "All pollinators" is the total abundance at each garden for all plotted pollinator guilds. Pollinator activity is plotted on a log10 scale to allow visualization of low-abundance pollinators, and is based on counts conducted for two, ten-minute periods for each plot on nine occasions during the growing season 
Table 5. ANCOVA results including interaction between pollinator guild and proportion native area in gardens. Model R2=0.224; F19d,1276=19.35; $P<0.001$. For individual interaction effect sizes, see Table 6.

\begin{tabular}{llccl}
\hline Effects & df & SS & F & P \\
\hline $\begin{array}{l}\text { Proportion native } \\
\text { area }\end{array}$ & 1 & 446.89 & 48.66 & $<0.001$ \\
$\begin{array}{l}\text { Plant density } \\
\text { Total area }\end{array}$ & 1 & 84.17 & 9.16 & $=0.003$ \\
$\begin{array}{l}\text { Pollinator guild } \\
\text { Pollinator guild* }\end{array}$ & 1 & 29.29 & 3.19 & $=0.074$ \\
proportion native & 8 & 2137.86 & 29.10 & $<0.001$ \\
area & & 610.87 & 8.31 & $<0.001$ \\
\hline
\end{tabular}

Table 6. Coefficients for each pollinator guild x proportion native plant interaction effect from the ANCOVA model (Table 5). Note that all slope values for pollinator guild vs. proportion native area are positive; coefficients represent difference from mean effect.

\begin{tabular}{llcl}
\hline $\begin{array}{l}\text { Interaction term (all } \\
\text { X Proportion native) }\end{array}$ & $\begin{array}{l}\text { Effect } \\
\text { coefficient }\end{array}$ & T-ratio & $\mathrm{P}$ \\
\hline Bublebee & 9.83 & 7.54 & \\
Honeybee & 1.65 & 1.27 & $<0.001$ \\
Small bee & -0.53 & -0.4 & 0.206 \\
Large bee & -1.078 & -0.83 & 0.686 \\
Small fly & -2.88 & -2.21 & 0.408 \\
Large fly & -1.73 & -1.33 & 0.027 \\
Butterfly & -3.24 & -2.48 & 0.013 \\
Wasp & 0.11 & 0.08 & 0.935 \\
\hline
\end{tabular}

\section{Discussion}

Programs meant to combat declining pollinator abundance by encouraging the planting of native species in urban gardens are widespread. However, empirical evidence for the success of this approach is equivocal (Bergerot et al., 2010; Hanley et al., 2014; Matteson and Langellotto, 2011). A complicating factor in assessing the efficacy of native gardens is that the effect of native flora may differ among plant species, and relative frequencies of pollinators may change through time. We thus took the approach of sampling several pollinator guilds, and at several times throughout the growing season. As expected, the overall frequency of pollinator visitation changed through time, presumably both reflecting pollinator phenology and changes in ambient temperature that affect the activities of insects (Bergman et al., 1996); the interaction effect between pollinator guild and time of year suggests that pollinator guilds have asynchronous life cycles (Ginsberg, 1983), perhaps timed to coincide with the availability of resources that they depend on (Tuell et al., 2008).

The present results suggest that gardens with higher proportion native flora exhibit elevated pollinator activity, and that the various pollinator guilds contribute differently to this overall effect. In agreement with previous work (Smith et al., 2006), we found 
no relationship between total garden area and pollinator abundance, although we found an effect of plant density on pollinator activity. However, the main result showing an effect of native flora on pollinator activity persists after controlling for both plant density and total cultivated area.

Because pollinator activity is corrected for time of year, and because proportion native area is arcsine-squareroot transformed prior to analysis, the biological interpretation of the coefficients from the multiple regression is not straightforward. However, back-transforming the regression predictor equation suggests that the effect of proportion native area is strong: the expectation is for one additional pollinator per minute for an increase of about $20 \%$ in the area cultivated with native plants.

An observational study of the effects of native flora has the advantage that the species and range of native flora are known a priori to reflect realistic choices of gardeners. However, like all observational studies, causation cannot be drawn from the observed relationships. For example, no attempt is made to manipulate gardens to represent a random sample of native and non-native species. Thus, the relationship between proportion native area and pollinator activity is more cautiously interpreted as valid for the particular flora cultivated by gardeners in the study. Neither could we control the range in the predictor variable; proportion native area. Although a manipulation experiment could theoretically include a range from 0 to $100 \%$, the present study included gardens composed of from 3\% to 53\% native area (Table 1). Furthermore, we cannot control for the effect of individual gardeners. It is conceivable that the most skilled gardeners plant a higher proportion native species-even after correcting for density and total garden area-which somehow results in higher pollinator activity.

An observational study does not experimentally control the choices of native and non-native flora with respect to their timing of flowering. Because peak abundance of the various pollinator guilds does not coincide, results may be explained by the influence of particular plant species (Goulson et al., 2008; Hanley et al., 2014), perhaps because of their flowering phenology and the resulting seasonal availability of floral rewards. It is possible that gardens with greater proportion native area provided resources more continuously than gardens dominated by non-native species. For example, Asclepias incarnata (swamp milkweed) has been shown to be a native flower highly attractive to North American bumblebees (Tuell et al., 2008), and its presence likely influenced pollinator visitation to the gardens where it was abundant in this study (see Appendix). Also, because plant phenology interacts with environmental variation (Hughes and Simons, 2014), patterns of visitation are expected to differ among years.

Many native flowers adapted to local conditions bloom in the late summer in eastern North America (Tuell et al., 2008), whereas many non-native plants had finished flowering by the end of the observation period. This difference may help explain the effect of native area on pollinator activity, specifically through increases in the frequency of bumblebees and large bees. Some species of large univoltine solitary bees (andrenids and megachilids) appear either early or late in the summer (Ginsberg, 1983), and late species are known to specialize on late-blooming Solidago spp. (Ginsberg, 1983). Small bees-which did not show a strong preference for native flowers-appeared early in the season when the abundance of native flowers was low in comparison to later in the summer. Flower morphology may also contribute to the effect of native flora on pollinator activity. For example, syrphid flies were frequently found foraging on native umbelliferous flowers, which are characterized by shallow corollas that allow access to 
both pollen and nectar (Colley and Luna, 2000), and there were few common non-native umbelliferous flowers in the gardens. Much debate surrounds the effect of native flora on lepidopterans; (Bergerot et al., 2010; Burghardt et al., 2009; Matteson and Langellotto, 2011; Tallamy and Shropshire, 2009); however the low abundance of butterflies observed in this study precludes any inferences here.

Pollinator diversity observed here is not meant to be representative of the pollinator composition in the Ottawa area. First, bee species may vary in abundance and richness among years (Dupont et al., 2009; McFrederick and LeBuhn, 2006). Second, the landscape matrix surrounding gardens (Hennig and Ghazoul, 2012) and the proximity of sites of reproduction (nests/hives etc.) to gardens (Greenleaf et al., 2007) may influence pollinator activity on a more local scale. It should also be noted that our response variable is pollinator activity, and not pollination success. Any useful extrapolation from this study must thus assume that pollinator activity is positively associated with pollination.

A commonly cited mechanism underlying the benefits of native flora is the coevolutionary history of plants and their pollinators: exotic flowers may be either less accessible and/or attractive to native insect pollinators (Comba et al., 1999; Corbet et al., 2001). It has been pointed out that, in the context of coevolution, a comparison of native and exotic plant species does not satisfactorily address mechanisms underlying pollinator attraction, and a more relevant consideration is the shared biogeographic distribution of plants and their pollinators (Hanley et al., 2014). This insight, however, is complicated by the fact that shared biogeography at the species scale does not necessarily imply an expectation of coevolution, because intraspecific genetic population differentiation in plant life history traits including flowering phenology is common (Wagner and Simons, 2009), and plant traits involved in pollination are expected to evolve in response to uncertainty in pollinator availability (Burd et al., 2009; Simons, 2011; Thomann et al., 2013).

In conclusion, this study has shown a positive relationship between pollinator activity and proportion of a garden planted with native flowers. Observational studies such as this can provide insight into effects that occur over realistic ranges of independent variables (here, cultivation decisions taken freely by real gardeners), but trade-off this realism for the ability to ascertain underlying causes of the relationship. Even if, as suggested by our data, the increase in pollinator activity is dependent on the particular flora chosen and effects differ among pollinator guilds, programs that encourage the cultivation of native flora are expected to succeed in increasing pollinator activity in general, assuming that the gardeners' choices of plant species in this study are a representative sample of choices in the general gardening public. Although the mechanisms underlying the relationship between degree of nativeness and pollinator activity must still be worked out, this study demonstrates that this relationship exists.

Acknowledgements. The authors thank K. Henein and P. Hennesey for comment, and the participating homeowners in Ottawa for property access. This research was supported by a Natural Sciences and Engineering Research Council (of Canada) Discovery Grant to AMS. 


\section{REFERENCES}

[1] Aizen, M.A., Feinsinger, P. (1994): Forest fragmentation, pollination, and plant reproduction in a Chaco dry forest, Argentina. - Ecology 75:330-351. doi: $10.2307 / 1939538$.

[2] Aizen, M.A., Harder, L.D. (2009): The Global Stock of Domesticated Honey Bees Is Growing Slower Than Agricultural Demand for Pollination. - Current Biology 19:915918. doi:10.1016/j.cub.2009.03.071.

[3] Ashman, T.L. et al. (2004): Pollen limitation of plant reproduction: Ecological and evolutionary causes and consequences. - Ecology 85:2408-2421. doi:10.1890/03-8024.

[4] Bergerot, B., Fontaine, B., Renard, M., Cadi, A., Julliard, R. (2010): Preferences for exotic flowers do not promote urban life in butterflies. - Landscape and Urban Planning 96:98-107. doi:10.1016/j.landurbplan.2010.02.007.

[5] Bergman, P., Molau, U., Holmgren, B. (1996): Micrometeorological impacts on insect activity and plant reproductive success in an alpine environment, Swedish Lapland. Arctic and Alpine Research 28:196-202. doi:10.2307/1551760.

[6] Biesmeijer, J.C. et al. (2006): Parallel declines in pollinators and insect-pollinated plants in Britain and the Netherlands. - Science 313:351-354. doi:10.1126/science.1127863.

[7] Brittain, C.A., Vighi, M., Bommarco, R., Settele, J., Potts, S.G. (2010): Impacts of a pesticide on pollinator species richness at different spatial scales. - Basic and Applied Ecology 11:106-115. doi:10.1016/j.baae.2009.11.007.

[8] Bryden, J., Gill, R.J., Mitton, R.A.A., Raine, N.E., Jansen, V.A.A. (2013): Chronic sublethal stress causes bee colony failure. - Ecology Letters 16:1463-1469. doi:10.1111/ele.12188.

[9] Burd, M. et al. (2009): Ovule Number Per Flower in a World of Unpredictable Pollination. - American Journal of Botany 96:1159-1167. doi:10.3732/ajb.0800183.

[10] Burghardt, K.T., Tallamy, D.W., Shriver, W.G. (2009): Impact of Native Plants on Bird and Butterfly Biodiversity in Suburban Landscapes. - Conservation Biology 23:219-224. doi:10.1111/j.1523-1739.2008.01076.x.

[11] Calderone, N.W. (2012): Insect Pollinated Crops, Insect Pollinators and US Agriculture: Trend Analysis of Aggregate Data for the Period 1992-2009. - Plos One 7 doi:e37235 10.1371/journal.pone.0037235.

[12] Cameron, S.A., Lozier, J.D., Strange, J.P., Koch, J.B., Cordes, N., Solter, L.F., Griswold, T.L. (2011): Patterns of widespread decline in North American bumble bees. Proceedings of the National Academy of Sciences of the United States of America 108:662-667. doi:10.1073/pnas.1014743108.

[13] Colla, S.R., Gadallah, F., Richardson, L., Wagner, D., Gall, L. (2012): Assessing declines of North American bumble bees (Bombus spp.) using museum specimens. - Biodiversity and Conservation 21:3585-3595. doi:10.1007/s10531-012-0383-2.

[14] Colley, M.R., Luna, J.M. (2000): Relative attractiveness of potential beneficial insectary plants to aphidophagous hoverflies (Diptera : Syrphidae). - Environmental Entomology 29:1054-1059. doi:10.1603/0046-225x-29.5.1054.

[15] Comba, L., Corbet, S.A., Hunt, L., Warren, B. (1999): Flowers, nectar and insect visits: Evaluating British plant species for pollinator-friendly gardens. - Annals of Botany 83:369-383. doi:10.1006/anbo.1998.0835.

[16] Connor, E.F., Hafernik, J., Levy, J., Moore, V.L., Rickman, J.K. (2002): Insect conservation in an urban biodiversity hotspot: The San Francisco Bay Area. - Journal of Insect Conservation 6:247-259. doi:10.1023/a:1024426727504.

[17] Corbet, S.A. et al. (2001): Native or exotic? Double or single? Evaluating plants for pollinator-friendly gardens. - Annals of Botany 87:219-232. doi:10.1006/anbo.2000.1322.

[18] Cox-Foster, D.L. et al. (2007): A metagenomic survey of microbes in honey bee colony collapse disorder. - Science 318:283-287. doi:10.1126/science.1146498. 
[19] Dietzsch, A.C., Stanley, D.A., Stout, J.C. (2011): Relative abundance of an invasive alien plant affects native pollination processes. - Oecologia 167:469-479. doi:10.1007/s00442011-1987-z.

[20] Dupont, Y.L., Padron, B., Olesen, J.M., Petanidou, T. (2009): Spatio-temporal variation in the structure of pollination networks. - Oikos 118:1261-1269. doi:10.1111/j.16000706.2009.17594.x.

[21] Finley, J., Camazine, S., Frazier, M. (1996): The epidemic of honey bee colony losses during the 1995-1996 season. - American Bee Journal 136:805-808.

[22] Fitzpatrick, U., Murray, T.E., Paxton, R.J., Breen, J., Cotton, D., Santorum, V., Brown, M.J.F. (2007): Rarity and decline in bumblebees - A test of causes and correlates in the Irish fauna. - Biological Conservation 136:185-194. doi:10.1016/j.biocon.2006.11.012.

[23] Frankie, G.W., Thorp, R.W., Schindler, M., Hernandez, J., Ertter, B., Rizzardi, M. (2005): Ecological patterns of bees and their host ornamental flowers in two northern California cities. - Journal of the Kansas Entomological Society 78:227-246. doi:10.2317/0407.08.1.

[24] Gallai, N., Salles, J.M., Settele, J., Vaissiere, B.E. (2009): Economic valuation of the vulnerability of world agriculture confronted with pollinator decline. - Ecological Economics 68:810-821. doi:10.1016/j.ecolecon.2008.06.014.

[25] Ginsberg, H.S. (1983): Foraging ecology of bees in an old field. - Ecology 64:165-175. doi: $10.2307 / 1937338$.

[26] Goddard, M.A., Dougill, A.J., Benton, T.G. (2010): Scaling up from gardens: biodiversity conservation in urban environments. - Trends in Ecology \& Evolution 25:90-98. doi:10.1016/j.tree.2009.07.016.

[27] Goulson, D., Lye, G.C., Darvill, B. (2008): Decline and conservation of bumble bees. In: Annual Review of Entomology, vol 53. Annual Review of Entomology. pp 191-208. doi:10.1146/annurev.ento.53.103106.093454.

[28] Greenleaf, S.S., Williams, N.M., Winfree, R., Kremen, C. (2007): Bee foraging ranges and their relationship to body size. - Oecologia 153:589-596. doi:10.1007/s00442-0070752-9.

[29] Hanley, M.E., Awbi, A.J., Franco, M. (2014): Going native? Flower use by bumblebees in English urban gardens. - Annals of Botany 113:799-806. doi:10.1093/aob/mcu006.

[30] Hennig, E.I., Ghazoul, J. (2012): Pollinating animals in the urban environment. - Urban Ecosystems 15:149-166. doi:10.1007/s11252-011-0202-7.

[31] Hughes, P.W.D., Simons, A.M. 2014. The continuum between semelparity and iteroparity: Plastic expression of parity in response to season length manipulation in Lobelia inflata. BMC Evolutionary Biology 14:90. doi: 10.1186/1471-2148-14-90.

[32] Klein, A.M., Vaissiere, B.E., Cane, J.H., Steffan-Dewenter, I., Cunningham, S.A., Kremen, C., Tscharntke, T. (2007): Importance of pollinators in changing landscapes for world crops. - Proceedings of the Royal Society B-Biological Sciences 274:303-313. doi:10.1098/rspb.2006.3721.

[33] Koutika, L.S., Rainey, H.J., Dassonville, N. (2011): Impacts of Solidago gigantea, Prunus serotina, Heracleum mantegazzianum and Fallopia japonica invasions on ecosystems. Applied Ecology and Environmental Research 9:73-83.

[34] Matteson, K.C., Langellotto, G.A. (2011): Small scale additions of native plants fail to increase beneficial insect richness in urban gardens. - Insect Conservation and Diversity 4:89-98. doi:10.1111/j.1752-4598.2010.00103.x.

[35] McFrederick, Q.S., LeBuhn, G. (2006): Are urban parks refuges for bumble bees Bombus spp. (Hymenoptera : Apidae)? - Biological Conservation 129:372-382. doi:10.1016/j.biocon.2005.11.004.

[36] Mysliwy, M. (2014): PLANT INVASIONS ACROSS DIFFERENT HABITAT TYPES AT FLORISTIC SURVEY. - Applied Ecology and Environmental Research 12:193-207.

[37] Ollerton, J., Winfree, R., Tarrant, S. (2011): How many flowering plants are pollinated by animals? - Oikos 120:321-326. doi:10.1111/j.1600-0706.2010.18644.x. 
[38] Potts, S.G., Biesmeijer, J.C., Kremen, C., Neumann, P., Schweiger, O., Kunin, W.E. (2010): Global pollinator declines: trends, impacts and drivers. - Trends in Ecology \& Evolution 25:345-353. doi:10.1016/j.tree.2010.01.007.

[39] Schemske, D.W., Willson, M.F., Melampy, M.N., Miller, L.J., Verner, L., Schemske, K.M., Best, L.B. (1978): Flowering ecology of some srping woodland herbs. - Ecology 59:351-366. doi:10.2307/1936379.

[40] Simons, A.M. (2003): Invasive aliens and sampling bias. - Ecology Letters 6:278-280.

[41] Simons, A.M. (2011): Modes of response to environmental change and the elusive empirical evidence for bet hedging. - Proceedings of the Royal Society B-Biological Sciences 278:1601-1609. doi:10.1098/rspb.2011.0176.

[42] Smith, R.M., Warren, P.H., Thompson, K., Gaston, K.J. (2006): Urban domestic gardens (VI): environmental correlates of invertebrate species richness. - Biodiversity and Conservation 15:2415-2438. doi:10.1007/s10531-004-5014-0.

[43] Stokstad, E. (2006): Ecology - Pollinator diversity declining in Europe. - Science 313:286-286.

[44] Tallamy, D.W., Shropshire, K.J. (2009): Ranking Lepidopteran Use of Native Versus Introduced Plants. - Conservation Biology 23:941-947. doi:10.1111/j.15231739.2009.01202.x.

[45] Thomann, M., Imbert, E., Devaux, C., Cheptou, P.O. (2013): Flowering plants under global pollinator decline. - Trends in Plant Science 18:353-359. doi:10.1016/j.tplants.2013.04.002.

[46] Thomson, D. (2004): Competitive interactions between the invasive European honey bee and native bumble bees. - Ecology 85:458-470. doi:10.1890/02-0626.

[47] Tuell, J.K., Fiedler, A.K., Landis, D., Isaacs, R. (2008): Visitation by wild and managed bees (Hymenoptera : Apoidea) to eastern US native plants for use in conservation programs. - Environmental Entomology 37:707-718. doi:10.1603/0046225x(2008)37[707:vbwamb]2.0.co;2.

[48] Vanbergen, A.J. et al. (2013): Threats to an ecosystem service: pressures on pollinators. Frontiers in Ecology and the Environment 11:251-259. doi:10.1890/120126.

[49] Wagner, I., Simons, A.M. (2009): Divergence among arctic and alpine populations of the annual, Koenigia islandica: morphology, life-history, and phenology. - Ecography 32:114-122.

[50] Withgott, J. (1999): Pollination migrates to top of conservation agenda - A collaborative effort on migratory pollinators aims to increase research, education, and conservation efforts. - Bioscience 49:857-862. doi:10.2307/1313643.

\section{APPENDIX}

Appendix 1. List of Ontario native flowers cultivated in the study gardens.

\begin{tabular}{|l|l|l|l|}
\hline $\begin{array}{l}\text { Blooming } \\
\text { Season }\end{array}$ & Common name & Scientific name & $\begin{array}{l}\text { Observed pollinator } \\
\text { type }\end{array}$ \\
\hline Spring & Largeflower bellwort & Uvularia grandiflora & \\
\cline { 2 - 4 } & Marsh violet & Viola palustris & \\
\cline { 2 - 4 } & Virginia bluebells & Mertensia virginica & \\
\cline { 2 - 4 } & Columbine & Aquilegia canadensis & \\
\cline { 2 - 4 } & Dutchman's breeches & Dicentra cucullaria & \\
\cline { 2 - 4 } & Wild bleeding heart & Dicentra eximia & \\
\cline { 2 - 4 } & Celandine poppy & Stylophorum diphyllum & \\
\cline { 2 - 4 } & White trillium & Trillium grandiflorum & \\
\hline Late spring & Canada anemone & Anemone canadensis & \\
\hline
\end{tabular}




\begin{tabular}{|c|c|c|c|}
\hline \multirow{4}{*}{ Early summer } & Foxglove beard-tongue & Penstemon digitalis & \\
\hline & Hairy beard-tongue & Penstemon hirsutus & \\
\hline & Wild geranium & Geranium maculatum & Small bees \\
\hline & Pale corydalis & Corydalis sempervirens & \\
\hline $\begin{array}{l}\text { Early-mid } \\
\text { summer }\end{array}$ & Harebell & Campanula rotundifolia & Small bees \\
\hline \multirow[t]{17}{*}{ Mid summer } & Beebalm & Monarda didyma & $\begin{array}{l}\text { Bumblebees, small } \\
\text { and large bees }\end{array}$ \\
\hline & Yerrow & Achillea millefolium & \\
\hline & Black-eyed Susan & Rudbeckia hirta & Large flies, others \\
\hline & Cup-plant & Silphium perfoliatum & \\
\hline & Giant hyssop & Agastache foeniculum & Bumblebees, \\
\hline & Spiderwort & Tradescantia ohioensis & $\begin{array}{l}\text { Bumblebees, small } \\
\text { bees }\end{array}$ \\
\hline & Purple coneflower & Echinacea purpurea & $\begin{array}{l}\text { Bumblebees, large } \\
\text { flies, others }\end{array}$ \\
\hline & Lanceleaf tickseed & Coreopsis lanceolata & \\
\hline & Turtlehead & Chelone glabra & $\begin{array}{l}\text { Bumblebees } \\
\text { Small and large bees, }\end{array}$ \\
\hline & Swamp wilkweed & Asclepias incarnata & $\begin{array}{l}\text { Bumblebees, honey } \\
\text { bees, small and large } \\
\text { bees, wasps, } \\
\text { butterflies, others }\end{array}$ \\
\hline & Butterfly weed & Asclepias tuberosa & Butterfly \\
\hline & Blue vervain & Verbena hastata & \\
\hline & Tall meadow-rue & Thalictrum pubescens & \\
\hline & Daisy fleabane & Erigeron annuus & \\
\hline & Boneset & Eupatorium perfoliatum & \\
\hline & Wild mint & Mentha arvensis & \\
\hline & Evening-primrose & Oenothera biennis & \\
\hline \multirow{3}{*}{$\begin{array}{l}\text { Mid-late } \\
\text { summer }\end{array}$} & Pearly everlasting & Anaphalis margaritacea & \\
\hline & False sunflower & Heliopsis helianthoides & Bumblebees, \\
\hline & Joe pye weed & Eupatorium purpureum & $\begin{array}{l}\text { Bumblebees, small } \\
\text { bees }\end{array}$ \\
\hline \multirow[t]{8}{*}{ Late summer } & New England aster & Aster novae-angliae & $\begin{array}{l}\text { Bumblebees, small } \\
\text { flies }\end{array}$ \\
\hline & White wood aster & Eurybia divaricata & \\
\hline & Smooth blue aster & Symphyotrichum laeve & $\begin{array}{l}\text { Bumblebees, small } \\
\text { bees, small flies }\end{array}$ \\
\hline & Obedient plant & Physostegia virginiana & $\begin{array}{l}\text { Bumblebees, large } \\
\text { bees, small bees }\end{array}$ \\
\hline & Canada goldenrod & Solidago canadensis & $\begin{array}{l}\text { Bumblebees, small } \\
\text { flies, }\end{array}$ \\
\hline & Zigzag goldenrod & Solidago flexicaulis & Bumblebees \\
\hline & Gray goldenrod & Solidago nemoralis & \\
\hline & Stiff goldenrod & Solidago rigida & \\
\hline
\end{tabular}

Observed pollinator type is identified based on casual observation, thus not conclusive. 